\title{
Urgensi Dakwah dan Problematika Masyarakat Global
}

\author{
Munawir Haris \\ Sekolah Tinggi Agama Islam Negeri (STAIN) Sorong Papua Barat \\ irfani.fanani@gmail.com
}

\begin{abstract}
Globalization influences all aspect of life, whether it is in social field, politic, economy, culture, education and in others field produced the kinds of influencing as positive and negative. There is an interesting development that writer finds in global society that the tendency of society has begun changing on quest of meaning life whether humanism and spiritual value. It relates with presenting of negative influencing of era globalization toward the society who forget the behavior as one of the part of eternity orientation. To answering that problem, Islam has given solution with the lesson in molded of Nashaihul 'Ibad holy book translation. The writer chooses the product of Imam Nawawi al-Bantani because the holy book includes many materials in Islam guiding that are really interesting to be observed and the content can be contextualized to the global society.
\end{abstract}

Keywords: Globalization, Problematic, Society, Islam Guiding, Nashāihul 'Ibād. 


\section{Pendahuluan}

Perkembangan zaman dewasa ini tidak dapat dipungkiri membuat masyarakat semakin terjebak pada era globalisasi. Segala aspek kehidupan baik di bidang sosial, politik, ekonomi, budaya, maupun di bidang yang lain selalu berbenturan dengan teknologi yang diharapkan dapat meningkatkan mutu kehidupan. Hal ini merupakan salah satu karakteristik era globalisasi yang mempunyai dampak positif dan negatif terhadap segala bidang kehidupan. Di antara beberapa manfaat positif tersebut adalah masyarakat dituntut untuk berpikir kreatif, inovatif dan selalu lebih maju, mengalami perubahan tata nilai dan sikap, adanya pergeseran nilai, dan sikap masyarakat yang semula irasional menjadi rasional. Berkembangnya ilmu pengetahuan dan teknologi (Iptek) membuat kehidupan lebih maju dan lebih mempermudah aktivitas kehidupan sehari-hari. Industrialisasi yang menghasilkan berbagai alat-alat komunikasi dan transportasi yang canggih merupakan salah satu usaha mengurangi pengangguran dan meningkatkan taraf hidup masyarakat. Sementara dampak negatif yang ditimbulkannya antara lain pola hidup konsumtif dan sikap individualistik. Masyarakat merasa dimudahkan dengan teknologi, membuat mereka merasa tidak lagi membutuhkan orang lain dalam beraktivitas, sehingga mereka lupa bahwa mereka adalah makhluk sosial, dan gaya hidup kebarat-baratan (westernisasi).

Era global yang terjadi saat ini telah melahirkan berbagai pengaruh pada kehidupan umat manusia, tidak terkecuali umat Islam. Masyarakat cenderung mengesampingkan nilai-nilai agama dan lebih mementingkan budaya hidup glamor, individual, hedonistik, dan materialistik. Namun demikian, ada perkembangan yang menarik bahwa kecenderungan masyarakat sudah mulai beralih pada pencarian makna kehidupan, baik nilai humanisme maupun spiritual. Spiritual dalam pengertian luas merupakan hal yang berhubungan dengan spirit. Sesuatu yang spiritual memiliki kebenaran yang abadi yang berhubungan dengan tujuan hidup manusia, sering dibandingkan dengan sesuatu yang bersifat duniawi, dan sementara. Spiritualitas semakin mendapat tempat tersendiri dalam masyarakat modern. Fenomena keagamaan ini semakin menarik untuk 
dicermati karena akhir-akhir ini terdapat kecenderungan rekonsiliasi antara nilai sufistik dan dunia modern. Kecenderungan baru dimensi spiritualitas yang bersumber dari agama mulai dilirik kembali oleh masyarakat. Kemajuan yang telah mereka raih dalam bidang Iptek membuktikan problem yang muncul akibat kemajuan dunia global belum terpecahkan. Sebagaimana anggapan banyak kalangan bahwa krisis besar yang melanda umat manusia tidak akan dapat diatasi dengan keunggulan Iptek dan kebesaran ideologi yang dianut oleh negara terkemuka. Maka dari itu, agama kemudian dijadikan sebagai harapan dan benteng terakhir untuk menyelamatkan manusia dari kehancuran tersebut. Kemajuan Iptek pada saat sekarang menjadi manusia congkak, materialis, menjauh dari agama, dan Tuhan tidak diperlukan lagi. Karena sudah tersedia peralatan yang serba praktis, instan, ringan, dan telah memperoleh tingkat kesenangan di dunia. Di kalangan masyarakat modern di perkotaan terdapat gejala yang menarik yakni dunia spiritual. Mereka yang masih jauh dari agama kemudian mendekati agama, mempelajari, dan mengamalkan agama dalam kehidupan sehari-hari.

Beberapa aspek penting spiritualitas dari masyarakat modern, menurut Bukhardt, ${ }^{1}$ antara lain: 1 ) berhubungan dengan sesuatu yang tidak diketahui atau ketidakpastian dalam kehidupan, 2) menemukan arti dan tujuan hidup, 3) menyadari kemampuan untuk menggunakan sumber dan kekuatan dalam diri sendiri, dan 4) mempunyai perasaan keterikatan dengan diri sendiri, dan dengan Yang Maha Tinggi. Kecenderungan masyarakat modern pada spiritualitas adalah pencarian makna hidup, perdebatan intelektual, dan peningkatan wawasan, spiritualitas sebagai katarsis atau obat dari problem psikologi, mengikuti tren dan perkembangan wacana, sikap mengeksploitasi agama untuk kebutuhan ekonomi. $^{2}$

1 Margareth A. Burkhadrt, "Characteristics of Spirituality in the Lives of Women in a Rural Appalachian Community," Journal of Transcultural Nursing, Vol. 4, Issue 2 (1993).

2 Pendapat Komarudin Hidayat dalam workshop "Urban Sufism, Alternative Paths to Liberalism and Modernity in Contemporary Islam, dalam Ma'ruf Mutaqien, "Eskapisme Masyarakat Modern," http://immciputat20.blogspot.co.id/2005/08/klipingmedia.html. Diakses pada 20 April 2018. 
Hakikat perjalanan hidup manusia berorientasi pada dua hal, yaitu dunia dan akhirat. Keduanya harus dilakukan secara seimbang. Manusia pada mulanya tidak ada kemudian ada, adanya manusia bukan ada dengan sendirinya melainkan ada yang mengadakan, yang mengadakan atau menciptakan manusia adalah Allah SWT. Allah yang menciptakan manusia dengan segala kelengkapannya memiliki dua tujuan. Pertama, manusia menjadi 'abdullāh atau hamba Allah. Ibadah dapat diartikan sebagai bentuk penyerahan total kepada Allah dengan melaksanakan apa yang menjadi perintah-Nya. Dalam pengertian sempit, beribadah adalah melakukan aktivitas-aktivitas ritual yang dilakukan dengan penuh pemahaman. Kedua, manusia sebagai khalifah Allah di bumi, yaitu khalifah yang diangkat dan diberhentikan oleh Allah untuk melaksanakan tugas-tugas sesuai kehendak dan aturan-Nya, dalam bidang keahlian dan atau kewenangan sesuai yang dikaruniakan Allah kepadanya. Tetapi, hal ini tidak berarti karena Allah tidak mampu, atau menjadikan manusia berkedudukan sebagai Tuhan. Allah bermaksud dengan pengangkatan itu untuk menguji manusia dan memberinya penghormatan. Jadi, esensi tugas manusia sebagai khalifah Allah di bumi adalah melaksanakan amanah sesuai tuntunan Allah dan rasul-Nya.

Manusia pada hakikatnya adalah makhluk yang sejak lahir telah mengakui adanya Tuhan. Hal ini telah dijelaskan dalam al-Qur'an Surat ar-Ruum ([30]: 30) berikut ini:

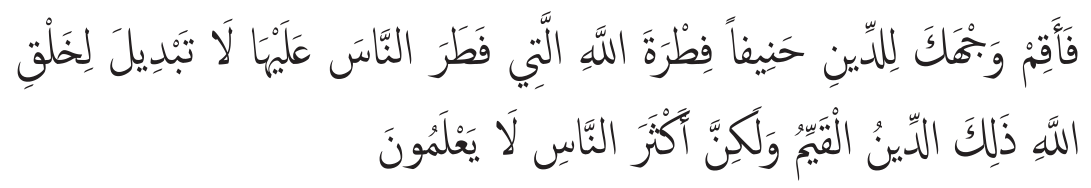

Maka hadapkanlah wajahmu dengan Lurus kepada agama Allah; (tetaplah atas) fitrah Allah yang telah menciptakan manusia menurut fitrah itu. tidak ada peubahan pada fitrah Allah. (Itulah) agama yang lurus; tetapi kebanyakan manusia tidak mengetahui. ${ }^{3}$

3 Depag RI. Al-Qur'an dan Terjemahnya (Jakarta: Lembaga Pentafsir dan Penterjemah Al-Qur'an, 1997), 645 
Dalam kehidupannya, manusia mempunyai fitrah (potensi). Fitrah adalah unsur-unsur dan sistem yang dianugerahkan Allah kepada setiap manusia, unsur-unsur itu mencakup jasmani, nafs, dan iman. Fitrah iman kepada Allah menjadi dasar sekaligus inti bagi tiga fitrah lainnya. Potensi iman dipandang sebagai dasar dan inti karena jika iman seseorang telah berkembang dan berfungsi dengan baik, fitrah yang lain akan berkembang dan berfungsi dengan baik pula. ${ }^{4}$

Dalam menciptakan manusia, Allah memberikan musibah. Musibah adalah kejadian apa saja yang menimpa manusia yang tidak dikehendaki. Oleh karena itu, seseorang kemudian memandangnya sebagai masalah. Musibah bisa menimpa siapa saja, ia bisa menimpa orang saleh dan bisa pula menimpa orang yang biasa berbuat maksiat. Manusia hidup di muka bumi ini tidak selamanya, tetapi ada batas akhir kehidupan yang disebut ajal atau kematian. Ada orang yang nyawanya berpisah dengan jasmaninya untuk sementara waktu, sesudah itu dikembalikan pada wadahnya sampai batas waktu datangnya saat pemisahan yang sempurna, yaitu orang yang sedang tidur. Ada pula orang yang perpisahan nyawa dengan jasmaninya bersifat sempurna yaitu orang yang saat kematiannya telah tiba. Setiap yang berjiwa akan mengalami kematian, Allah yang menciptakan manusia dan Allah pulalah yang menentukan batas akhir kehidupannya. ${ }^{5}$

Esensi tugas manusia dalam menjadi Khalifah $f i$ al-ardh tidak akan lepas dari kehidupan sosial, seperti habl min al-nās. Habl min al-nās yang diterapkan dalam kehidupan masyarakat tidak akan bisa lepas dari akhlak karena setiap semua perbuatan manusia selalu diibaratkan berbingkai dengan akhlak. Islam juga mengajarkan tiga pondasi dasar manusia, yaitu iman, Islam, dan ihsan (berperilaku baik). Jadi, berawal dengan kesadaran kepada Tuhan akan berimbas pada cerminan perilaku manusia atau yang selama ini dikenal dengan akhlak.

\footnotetext{
4 Anwar Sutoyo. Dasar-dasar Bimbingan dan Konseling Islam (Semarang: Cipta Prima Nusantara, 2007), 66.

5 Ibid., 63-65.
} 
Bertolak kembali kepada dampak negatif dari era globalisasi terhadap masyarakat yang melupakan akhlak sebagai salah satu bagian dari orientasi akhirat, agama Islam sebenarnya telah memberikan solusi untuk menghadapi permasalahan ini. Salah satu nilai yang bisa ditawarkan untuk menghadapi problem masyarakat global seperti di atas adalah dengan menawarkan materi bimbingan Islam yang tertuang dalam terjemahan kitab Nashāihul 'Ibād. Kitab ini dapat dijadikan acuan oleh masyarakat pada umumnya dan oleh orang tua pada khususnya untuk memberikan bimbingan berbasis akhlak. Islam memberikan solusi pada semua permasalahan yang sedang dihadapi masyarakat global saat ini. Islam merupakan agama yang kaya akan ilmu pengetahuan, begitu banyak ilmu yang tertuang dalam al-Qur'an maupun Hadis. Selain itu, para ulama juga banyak yang menulis kitab yang berisi ilmu pengetahuan yang dapat dijadikan sumber kajian ilmu ke-Islaman. Imam Nawawi al-Bantani adalah salah satu ulama yang sudah tidak asing lagi bagi umat Islam Indonesia. Imam Nawawi menulis kitab Nashāihul ' $I b \bar{a} d$ yang berisi tentang berbagai nasihat untuk umat Islam. Kitab ini sangat penting untuk dikaji dan isinya dapat dikontekstualisasikan pada masyarakat era global saat ini.

Penulis memilih karya Imam Nawawi al-Bantani dalam penelitian ini karena tokoh yang mempunyai intelektual yang tinggi di bidang ilmu-ilmu ke-Islaman ini begitu terkenal di kota Makkah dan Madinah, padahal beliau berasal dari Indonesia. Selain itu, penulis memilih terjemahan kitab Nashāihul 'Ibād karya Imam Nawawi al-Bantani dalam penelitian ini karena kitab ini berisi begitu banyak materi-materi bimbingan Islam yang bisa diamalkan oleh masyarakat untuk menghadapi tantangan era global saat ini agar meningkatkan keimanannya dan tidak mudah terpengaruh oleh hal-hal buruk, serta bisa mencapai kebahagiaan di dunia dan akhirat.

Terjemahan kitab Nashāihul 'Ibād karya Imam Nawawi al-Bantani berisi tentang pedoman dan rujukan berperilaku sesuai dengan tuntunan Islam yang dapat membawa pembaca ke arah kebaikan dan menjadikan pembaca berbudi pekerti santun dan berjiwa lembut. Kandungannya 
begitu dalam dan hakikatnya begitu tinggi sehingga bila dipahami secara mendalam dan dipraktikkan dengan ikhlas kesucian jiwa dan kesantunan budi pekerti. Selain itu, kitab ini juga berisi Hadis-Hadis nabi dan atsar para sahabat beserta nasihat-nasihat para ulama dan ahli hikmah yang nilainya sangat tinggi, sehingga dapat mengingatkan kita akan pentingnya memahami makna hidup dan berbagai amal kebaikan serta budi pekerti. Atas dasar itulah, peneliti akan berusaha menganalisis lebih jauh tentang isi kitab tersebut.

\section{Problematika Masyarakat Global}

Globalisasi yang terjadi pada saat ini menyebabkan dampak positif dan negatif pada masyarakat. Masyarakat kini merasa dimudahkan dengan kemajuan teknologi. Mereka tidak lagi membutuhkan orang lain dalam beraktivitas, bahkan terkadang mereka juga lupa bahwa mereka adalah makhluk sosial. Kemajuan teknologi di sisi lain juga mengakibatkan pengangguran dalam masyarakat. Kemajuan di bidang teknologi pada zaman modern ini telah membawa manusia ke dalam dua sisi, yaitu bisa memberi nilai tambah (positif) dan negatif.

Efek positifnya tentu saja akan meningkatkan keragaman budaya melalui penyediaan informasi yang menyeluruh sehingga memberikan orang kesempatan untuk mengembangkan kecakapan-kecakapan baru dan meningkatkan produksi. Sedangkan efek negatifnya adalah kemajuan teknologi akan berbahaya jika digunakan oleh orang yang secara mental dan keyakinan agama belum siap. Mereka dapat menyalahgunakan teknologi untuk tujuan-tujuan yang destruktif dan mengkhawatirkan. Misalnya, penggunaan teknologi kontrasepsi dapat menyebabkan orang dengan mudah dapat melakukan hubungan seksual tanpa harus takut hamil. Jaringan-jaringan peredaran obat-obatan terlarang, tukar menukar informasi, penyaluran data-data film yang berbau pornografi di bidang teknologi komunikasi seperti komputer, internet, dan sebagainya akan semakin intensif penggunaannya.

Kehadiran ilmu pengetahuan dan teknologi (Iptek) melahirkan sejumlah problem di dalam masyarakat modern, antara lain, pertama, 
desintegrasi ilmu pengetahuan. Banyak ilmu yang berjalan sendiri-sendiri tanpa ada tali pengikat dan penunjuk jalan yang menguasai semuanya, sehingga kian jauhnya manusia dari pengetahuan akan kesatuan alam. Kedua, kepribadian yang terpecah. Karena kehidupan manusia modern dipolakan oleh ilmu pengetahuan yang coraknya kering nilai-nilai spiritual dan terkotak-kotak, maka manusia menjadi pribadi yang terpecah, hilangnya kekayaan rohaniah karena jauhnya dari ajaran agama. Ketiga, penyalahgunaan ilmu pengetahun dan teknologi. Berbagai iptek disalahgunakan dengan segala efek negatifnya sebagaimana disebutkan di atas. Keempat, pendangkalan iman. Manusia tidak tersentuh oleh informasi yang diberikan oleh wahyu, bahkan hal itu menjadi bahan tertawaan dan dianggap tidak ilmiah dan kampungan. Kelima, pola hubungan materialistik. Pola hubungan satu dan lainnya ditentukan oleh seberapa jauh antara satu dan lainnya dapat memberikan keuntungan yang bersifat material. Keenam, menghalalkan segala cara. Karena dangkalnya iman dan pola hidup materialistik manusia dengan mudah menghalalkan segala cara dalam mencapai tujuan. Ketujuh, stres dan frustasi. Manusia mengerahkan seluruh pikiran, tenaga, dan kemampuannya untuk terus bekerja tanpa mengenal batas dan kepuasan sehingga apabila ada hal yang tidak bisa dipecahkan mereka stres dan frustasi. Kedelapan, kehilangan harga diri dan masa depannya. Mereka menghabiskan masa mudanya dengan memperturutkan hawa nafsu dan menghalalkan segala cara. Namun, ada suatu saat akan tiba waktunya mereka tua segala tenaga, fisik, fasilitas, dan kemewahan hidup sudah tidak dapat mereka lakukan. Mereka merasa kehilangan harga diri dan masa depannya. ${ }^{6}$

Menurut Seyyed Hossein Nasr, seorang ilmuwan kenamaan dari Iran, berpandangan bahwa manusia modern dengan kemajuan teknologi dan pengetahuannya telah tercebur ke dalam lembah pemujaan terhadap pemenuhan materi semata, namun tidak mampu menjawab problem kehidupan yang sedang dihadapinya. Kehidupan yang dilandasi kebaikan tidaklah bisa hanya bertumpu pada materi melainkan pada dimensi

6 Zakiyuddin Bhaidawy, Dialog Global \& Masa Depan Agama (Surakarta: Muhammadiyah University Press, 2001), 30. 
spiritual. Jika hal tersebut tidak diimbangi akibatnya jiwa pun menjadi kering dan hampa. Semua itu adalah pengaruh dari sekularisme Barat yang menjalani hidup dengan prinsip materialistik.

Nasr berpendapat bahwa manusia Barat modern memperlakukan alam seperti pelacur. Mereka menikmati dan mengeksploitasi alam demi kepuasan dirinya tanpa rasa kewajiban dan tanggung jawab apapun. Menurut Nasr kondisi manusia modern sekarang mengabaikan kebutuhannya yang paling mendasar dan bersifat spiritual. Mereka gagal menemukan ketenteraman batin, yang berarti tidak ada keseimbangan dalam diri. Hal ini akan semakin parah apabila tekanannya pada kebutuhan materi semakin meningkat sehingga keseimbangan semakin rusak. Oleh karena itu, manusia memerlukan agama untuk mengobati krisis yang dideritanya.

Menurut Abdullah Nasihin Ulwan, umat Islam di era modern ini akan menghadapi beberapa permasalahan, yaitu tantangan setan, diri, dan hawa nafsu; tantangan ghazwul fikri; tantangan krisis moral; tantangan pemerintahan sekuler; dan tantangan pesimisme terhadap amal Islam. ${ }^{7}$ Menurut Asrowi, era modern atau biasa disebut era globalisasi ini menimbulkan terjadinya berbagai tekanan dan konflik di seluruh tatanan kehidupan manusia; semua umat manusia terlibat langsung dengan keadaan yang demikian itu tanpa terkecuali. Keadaan yang kurang tertata ini dimanfaatkan oleh para pelaku kejahatan untuk kepentingan sepihak, yang akhirnya timbul permasalahan baru. Permasalahan demi permasalaham yang muncul menyebabkan terjadinya berbagai macam penyakit, baik penyakit zahir maupun batin. Keadaan yang demikian itu membentuk satu lingkaran kehidupan yang pelik. Situasi seperti ini menyebabkan hilangnya kepedulian antara satu dengan yang lain, sehingga mereka akan melakukan segala hal atau menghalalkan segala cara untu memenuhi hajat hidup dan untuk kesembuhan penyakit mereka masing-masing. Sebelum hal ini terjadi lebih parah tentunya umat manusia perlu apotek universal yang berisi dengan obat-obatan

\footnotetext{
7 Abdullah Nasihin, Aktivitas Islam Menghadapi Tantangan Global (Solo: al-Alaq,
} 2003), 120. 
zahir maupun batin (spiritual) yang sesuai dengan fitrah manusia, dan tidak bertentangan dengan norma-norma, serta nilai yang berlaku di masyarakat secara umum.

Tekanan hidup yang dirasakan oleh manusia di era modern ini jika dibiarkan akan menumbuhkan hilangnya kesadaran manusia akan pentingnya kebersamaan, kerukunan, toleransi, sosial, keselarasan hidup, silaturrahmi, dan sebagainya. Tentunya, dalam mengatasi berbagai tekanan hidup ini tidak hanya cukup dengan menyelenggarakan adanya diskusi atau seminar, ceramah, lokakarya, pelatiahan atau yang lainnya. Akan tetapi, wajib adanya pembenahan secara langsung yang diawali oleh masing-masing individu secara terkonsep. Sebab dunia atau jagad ini khususnya Indonesia terbentuk dari komponen individu, jadi tekanan yang bersifat kompleks ini harus dibenahi oleh individu pula, dalam arti supaya tidak hanya saling memerintah kepada orang lain tetapi harus memerintah diri sendiri untuk berbenah. Pembenahan yang dilakukan oleh tiap individu ini perlu ada pengawasan (media control) yang dipelopori oleh orang yang merasa cukup siap menjadi pemimpin manusia, baik di tingkat keluarga maupun pemerintahan. ${ }^{8}$

Problematika masyarakat global terjadi di seluruh belahan dunia. Problematika masyarakat global di Barat yang meliputi kemiskinan, kelaparan, pemanasan global, perebutan kekuasaan antarnegara, gencatan senjata antarnegara, dan lain-lain. Sedangkan di Indonesia problematika tersebut meliputi berbagai krisis, seperti krisis ekonomi, krisis politik, krisis sosial, krisis budaya hingga krisis agama. Persoalan kemiskinan, pengangguran, keterbelakangan, ketidakadilan, kekerasan hingga penyalahgunaan kekuasaan, seakan-akan tidak mau beranjak dalam kehidupan bangsa Indonesia. Wajar apabila dalam berbagai hasil survei, Indonesia selalu saja menempati posisi rendah dalam hal kemajuan, dan berada pada posisi puncak dalam hal kemunduran.

Dalam bidang korupsi misalnya, pada 2007 Indonesia menempati urutan ketiga negara paling korup setelah Myanmar dan Kamboja.

\footnotetext{
${ }^{8}$ Ibid., 45.
} 
Begitu halnya dengan kemiskinan dan kebodohan. Sebaliknya, dalam bidang kemajuan ekonomi, ilmu pengetahuan, dan pendidikan, Indonesia berada di nomor belakang. Selain itu, krisis lainnya yang paling nyata dihadapi bangsa Indonesia adalah krisis kepemimpinan. Kita mengalami kegamangan dalam hal menentukan pemimpin yang tepat untuk negeri ini. Tentu saja pemimpin yang mampu mengeluarkan Indonesia dari berbagai krisis multidimensi. ${ }^{9}$

Kehidupan modern yang demikian kompetitif menyebabkan manusia harus mengerahkan seluruh pikiran, tenaga, dan kemampuan. Mereka terus bekerja dan bekerja tanpa mengenal batas dan kepuasan. Hasil yang dicapai tak pernah disyukurinya dan selalu merasa kurang. Apalagi jika usaha atau proyeknya gagal, mereka mudah kehilangan pegangan karena tidak lagi memiliki pegangan yang kokoh yang berasal dari Tuhan. Mereka hanya berpegang atau bertuhan pada hal-hal yang bersifat material yang sama sekali tidak dapat membimbingnya. Akibatnya, mereka sering stres dan frustasi. Jika hal ini terus berlanjut, sikap itu akan menjadikan seseorang stres, gila, bahkan hilang akal sehat atau ingatan. ${ }^{10}$

Problematika masyarakat global selanjutnya adalah hilangnya harga diri dan masa depannya. Hingga kini, banyak orang yang terjerumus atau salah memilih jalan kehidupan. Masa mudanya dihabiskan untuk memperturutkan hawa nafsu dan segala daya dan cara telah ditempuhnya. Namun, suatu saat sudah tua renta, fisiknya sudah tidak berdaya, tenaganya sudah tidak mendukung, dan berbagai kegiatan sudah tidak dapat ia lakukan. Manusia yang demikian ini merasa kehilangan harga diri dan masa depannya, ke mana harus berjalan, tidak tahu. Mereka perlu bantuan dari kekuatan yang berada di luar dirinya, yaitu bantuan Tuhan. ${ }^{11}$

Dari berbagai problematika masyarakat global di atas, dampak negatif lebih mendominasi daripada dampak positif. Dampak negatif

\section{Ibid., 57.}

${ }^{10}$ Seyyed Hossein Nasr, Tasawuf Dulu dan Sekarang (Jakarta: Pustaka Firdaus, 1985), 181.

${ }^{11}$ Abuddin Nata, Akhlak Tasawuf (Jakarta: PT. Raja Grafindo Persada, 1997), 105. 
yang banyak itu menimbulkan alienasi atau keterasingan manusia. Manusia merasa terasing di dalam keramaian, padahal banyak orang di sekitarnya. Hal ini disebabkan manusia tidak lagi membutuhkan bantuan orang lain; manusia kini lebih individual. Hal tersebut adalah gambarangambaran masyarakat modern yang obsesi keduniaannya tampak lebih dominan ketimbang spiritual. Kemajuan teknologi sains dan segala hal yang bersifat duniawi jarang disertai dengan nilai spiritual. Masyarakat global pun kini telah mengalami krisis spiritual.

\section{Urgensi Bimbingan Islam Bagi Masyarakat Global}

Dari problem di atas, maka sangat dibutuhkan adanya solusi untuk mengatasinya. Solusi yang pertama, menerima ujian dan cobaan dengan sabar dan tabah, karena ini merupakan kunci kedewasaan dari emosional. Kedua, dalam Islam prinsip keseimbangan antara duniawi dan ukhrawi merupakan suatu keharusan sebagaimana tergambar dalam perintah Allah dalam Surat al-Qashash ([28]: 77) berikut:

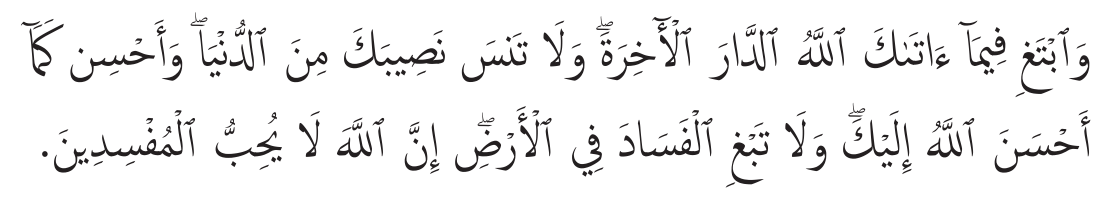

Dan carilah pada apa yang telah dianugerahkan Allah kepadamu (kebahagiaan) negeri akhirat, dan janganlah kamu melupakan bagianmu dari (kenikmatan) duniawi dan berbuat baiklah (kepada orang lain) sebagaimana Allah telah berbuat baik, kepadamu, dan janganlah kamu berbuat kerusakan di (muka) bumi. Sesungguhnya Allah tidak menyukai orang-orang yang berbuat kerusakan.

Prinsip keseimbangan inilah yang dikenal dalam bahasa al-Qur'an sebagai adil sebagaimana tertuang dalam perintah Allah dalam Surat anNahl ([16]: 90) dan Surat al-Maidah ([5]: 8), adil inilah syarat adanya keseimbangan di samping "keselarasan". Keselarasan dalam wacana tidak sama dengan keseimbangan dalam hitungan matematika yang menuntut pembagian sama rata antara dua belah pihak. Tetapi, adanya kepuasan 
batin (ridha) dari dua belah pihak tersebut. Ketiga, keberhasilan dalam meraih kebahagiaan di dunia dan akhirat sekaligus merupakan dambaan setiap manusia, itulah kiranya manusia tak henti-hentinya memanjatkan doa Rabbana atina fi al-dunya hasanah wa fi al-akhirati hasanah waqina 'adzaba an-nar (Ya Tuhan kami, berilah kami kebahagiaan di dunia dan akhirat serta jagalah kami dari api neraka). Hal ini dapat diperoleh siapapun sekaligus manakala ia memenuhi perintah Allah dan menjauhi larangan-Nya, di mana dan kapan pun ia berada, termasuk di zaman modern ini. Problem masyarakat modern yang dihiasi kemungkaran berupa tipu daya dan dosa bukan penghalang bagi kita untuk meraih keberhasilan hidup di dunia dan akhirat sekaligus. Selama kita mampu bertahan dalam jalur kebenaran dan tidak terhanyut dalam tradisi kemungkaran tersebut, lebih-lebih bila kita menyadari semua itu adalah ujian bagi kualitas takwa kita.

Keempat, solusi bagi seseorang yang dihantui perasaan berdosa yaitu, setiap manusia pasti pernah berbuat salah dan dosa dalam hidupnya, meskipun hanya sekali. Karena itu sudah menjadi sifat manusia sebagai makhluk pelupa dan pendosa. Akan tetapi, sebagai orang yang beriman kita yakin Allah adalah Tuhan Yang Maha Pengasih dan Pengampun kepada hambanya. Allah pasti memaafkan semua kesalahan dan dosa kita selama kita mau mohon ampun (bertaubat) kepada-Nya, sebagaimana firman Allah SWT dalam Surat al-Zumar ([39]: 53) yang artinya:

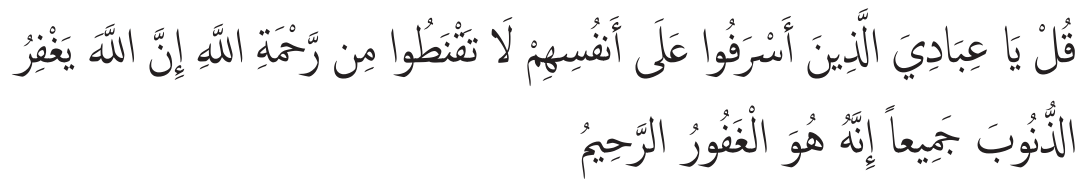

Katakanlah, "Hai hamba-hamba-Ku yang malampaui batas terhadap diri mereka sendiri, janganlah kamu berputus asa dari rahmat Allah. Sesungguhnya Allah mengampuni dosa-dosa semuanya. Sesungguhnya Dia-lah yang Maha Pengampun lagi Maha Penyayang.

Islam telah memberikan jalan keluar bagi seseorang yang dihantui perasaan berdosa, yaitu dengan memperbanyak membaca istighfar 
dengan keyakinan bahwa Allah akan mengampuni dosa kita.

Kelima, niat baik merupakan modal awal kita siap menjadi baik dan berarti kita telah mengkondisikan diri kita untuk selalu menuai kebaikan. Sebaliknya, jika dalam hati tertanam niat yang buruk, berarti kita mengkondisikan diri kita untuk menjadi buruk. Dalam kaitan ini perlu dibedakan antara keinginan yang sudah berbentuk niat dengan yang sebatas lintasan dalam jiwa (haditsun nafs). Kalau sebatas haditsun nafs kemudian sadar dan istighfar, maka masih ditolerir. ${ }^{12}$ Hati merupakan pusat bagi manusia. Hatilah yang menentukan baik tidaknya seseorang, hatilah yang mengarahkan manusia apakah menjadi baik atau jahat. Hati pula yang menunjukkan watak manusia sebenarnya. Bila hati seseorang bersih, bening, dan jernih, maka dirinya juga akan menampakkan kebersihan, kejernihan, dan kebeningan. Sebaliknya, bila hatinya kotor dan berpenyakit, maka akan mempengaruhi pada pikiran, ucapan, dan tindakannya sehingga yang keluar dari tubuhnya adalah pikiran, perkataan, dan tindakan yang kotor pula.

Kebersihan hati harus selalu dijaga dari penyakit yang akan menyerangnya. Sebab kalau hati sudah terkena penyakit, misalnya dengki, iri, ujub, riya', takabur, dan lainnya, maka akan segera menggerogoti anggota tubuh luarnya dalam bentuk perbuatan-perbuatan yang tidak baik kepada orang lain. Menjaga kesehatan hati (qalbu) lebih penting ketimbang kesehatan jasmani, sebab menurut al-Ghazali, penyakit anggota tubuh luar hanya akan membuat hilangnya kehidupan yang abadi.

Kesehatan qalbu ini harus dipelajari semua orang yang mempunyai akal budi, sebab qalbu tidak lepas dari penyakit yang kalau dibiarkan justru membuatnya marak, berkembang, dan tampak jelas. ${ }^{13}$ Untuk mengobati penyakit hati dan mencegahnya agar tidak datang lagi, maka terlebih dahulu kita harus mengetahui pembangkit dan penyebabnya. Penyebab utama dari penyakit hati tak lain adalah dorongan hawa nafsu yang selalu mendorong ke arah kejelekan, sebagaimana al-Qur’an dalam

${ }^{12}$ Amin Syukur, Tasawuf Kontekstual Solusi Problem Manusia Modern (Yogyakarta: Pustaka Pelajar, 2003), 177.

${ }^{13}$ Ibid., 190. 
Surat Yusuf ([12]: 53) berikut.

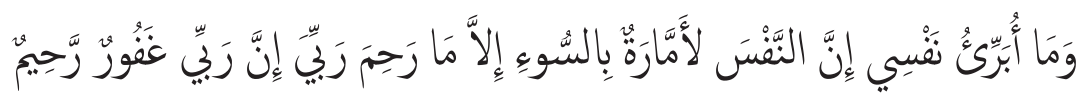

Dan aku tidak membebaskan diriku (dari kesalahan), karena Sesungguhnya nafsu itu selalu menyuruh kepada kejahatan, kecuali nafsu yang diberi rahmat oleh Tuhanku. Sesungguhnya Tuhanku Maha Pengampun lagi Maha Penyanyang.

Oleh karena itu, cara pencegahan dan pengobatannya dapat ditempuh melalui dua tahap. Pertama, berpaling sekuat tenaga dari tuntutan hawa nafsu dan membersihkan hati dari kotoran-kotoran yang menghinggapinya. Tahap ini disebut dengan takhalli, yakni pengosongan diri dari kejelekan. Kedua, meningkatkan ketakwaan kepada Allah dan membiasakan diri kita kepada kebaikan. Tahap ini disebut dengan tahalli, yakni menghiasi diri dengan kebaikan. Kalau kita berhasil menerapkan dua langkah tersebut secara simultan, maka hati kita akan cemerlang dan kita terhitung sebagai orang yang beruntung. ${ }^{14}$ Allah berfirman dalam Surat al-Syams ([91]: 9) sebagai berikut:

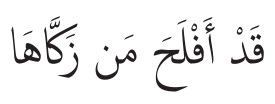

Sesungguhnya beruntunglah orang yang mensucikan jiwa itu.

Sedangkan yang tidak berhasil dan cenderung menuruti tuntutan hawa nafsu, maka itulah orang yang merugi. Firman Allah dalam Surat al-Syams ([91]: 10):

$$
\text { وَقَّْ خَابَ مَن دَسَّاهَا }
$$

Dan sesungguhnya merugilah orang yang mengotori jiwanya.

Namun, usaha-usaha itu ada kelebihan dan kekurangannya karena belum menyentuh hati masyarakat. Kekurangan itu perlu dilengkapi

\footnotetext{
${ }^{14}$ Syukur, Tasawuf Kontekstual, 194.
} 
dengan bimbingan Islam, karena ada kelebihan dari bimbingan Islam, yaitu mengingatkan individu yang dibimbing dengan cara Allah. Karena, pada dasarnya, individu telah memiliki iman, jika iman yang ada pada individu tidak tumbuh diduga individu lupa merawatnya, akibatnya iman tidak tumbuh dan berfungsi dengan baik. Selain itu, Allah telah mengutus rasul-Nya dengan membawa kitab suci sebagai pedoman hidup, jika ada individu yang mengalami kebingungan atau salah jalan diduga mereka belum memahami petunjuk itu. ${ }^{15}$ Tujuan dari bimbingan Islam adalah membantu individu mewujudkan dirinya menjadi manusia seutuhnya agar mencapai kebahagiaan hidup di dunia dan akhirat, membantu individu agar tidak menghadapi masalah, membantu individu mengatasi masalah yang sedang dihadapinya, membantu individu memelihara dan mengembangkan situasi dan kondisi yang baik atau yang telah baik agar tetap baik atau menjadi lebih baik sehingga tidak akan menjadi sumber masalah bagi dirinya sendiri dan orang lain. ${ }^{16}$

Berbagai macam bentuk bimbingan untuk pemecahan problematika masyarakat modern seperti bimbingan spiritual, bimbingan untuk mengatasi kebingungan dalam menentukan pilihan, bimbingan untuk membantu mereka yang terlanjur berbuat salah atau dosa, bimbingan pergaulan dengan orang yang bukan muhrim, bimbingan untuk pernikahan, bimbingan hidup dengan sesama Muslim, bimbingan hidup bersama orang tua, bimbingan untuk hati, bimbingan untuk menghadapi musibah, bimbingan untuk berbicara. ${ }^{17}$ Hakikat bimbingan dan konseling Qur'ani adalah upaya membantu individu belajar mengembangkan fitrah dan atau kembali kepada fitrah, dengan cara memberdayakan (empowering) iman, akal, dan kemauan yang dikaruniakan Allah SWT, kepadanya untuk mempelajari tuntunan Allah dan rasul-Nya, agar fitrah yang ada pada individu itu berkembang dengan benar dan kokoh sesuai

${ }^{15}$ Anwar Sutoyo, Bimbingan dan Konseling Islam (Semarang: CV. Cipta Prima Nusantara, 2007), 221.

16 Thohari Musnamar, Dasar-dasar Konseptual Bimbingan dan Konseling Islami (Yogyakarta: UII Press, 1992), 34.

${ }^{17}$ Sutoyo, Bimbingan dan Konseling Islam, 188. 
dengan tuntunan Allah SWT. ${ }^{18}$ Materi bimbingan Islam adalah materi yang disampaikan $d a^{\prime} i$ kepada mad'u atau konselor kepada klien. Dalam hal ini sudah jelas bahwa yang menjadi materi dalam bimbingan Islam adalah ajaran Islam. Materi bimbingan Islam dapat diklasifikasikan menjadi empat masalah pokok, yaitu akidah, akhlak, syariah, dan ibadah. ${ }^{19}$

\section{Pendekatan Sufistik Sebagai Materi Bimbingan Islam}

Bimbingan Islam banyak ragamnya, pendekatan yang dipakai seperti pendekatan teologi, pendekatan legal formal, pendekatan fikih, pendekatan liberalisme, dan pendekatan fundamentalisme. Masingmasing pendekatan tersebut ada kekurangan dan kelebihannya. Salah satu pendekatan yang digunakan atau dipilih dalam peneilitian ini adalah pendekatan sufistik. Melalui pendekatan sufistik seseorang dapat mengetahui tentang cara-cara melakukan pembersihan diri serta mengamalkannya secara benar. Dari pendekatan ini diharapkan manusia akan tampil sebagai orang yang pandai berinteraksi dengan orang lain, atau pada saat melakukan berbagai aktivitas dunia yang menuntut kejujuran, keikhlasan, tanggung jawab, dan sebagainya. Dari suasana yang demikian itu, tasawuf diharapkan dapat mengatasi berbagai penyimpangan moral yang mengambil bentuk seperti manipulasi, korupsi, kolusi, penyalahgunaan kekuasaan dan kesempatan, penindasan, dan sebagainya.

Di tengah-tengah situasi masyarakat yang cenderung mengarah kepada dekadensi moral seperti yang gejala-gejalanya mulai tampak saat ini, dan akibat negatifnya mulai terasa dalam kehidupan, masalah tasawuf mulai mendapatkan perhatian dan dituntut peranannya untuk terlibat secara aktif mengatasi masalah-masalah tersebut. Terjadinya kebakaran hutan dengan segala akibatnya yang merugikan, praktik pengguguran kandungan (aborsi), pemerkosaan, pembunuhan, penipuan, penyalahgunaan obat-obat terlarang, pergaulan bebas, yang mengarah pada

\footnotetext{
${ }^{18}$ Ibid., 24.

${ }^{19}$ Muhammad Munir \& Wahyu Ilaihi, Manajemen Dakwah (Jakarta: Prenada Media, 2006), 24.
} 
perilaku penyimpangan seksual, penimbunan harta kekayaan dengan dampaknya yang menjurus pada kesenjangan sosial, disia-siakannya masalah keadilan, dan lain sebagainya, adalah bermula dari kekotoran jiwa manusia, yaitu jiwa yang jauh dari bimbingan Tuhan karena tidak pernah mencoba mendekati-Nya. Untuk mengatasi masalah ini, tasawuflah yang paling memiliki potensi dan otoritas, karena di dalam tasawuf dibina secara intensif tentang cara-cara agar seseorang selalu merasakan kehadiran Tuhan dalam dirinya. Dengan cara demikian, ia akan malu berbuat menyimpang, karena merasa diperhatikan oleh Tuhan. ${ }^{20}$

Kembalinya masyarakat saat ini kepada tasawuf adalah cukup beralasan, karena secara historis, kehadiran tasawuf bermula sebagai upaya untuk mengatasi krisis akhlak yang terjadi di masyarakat Islam masa lalu, yaitu saat umat Islam di abad klasik (650-1250 M) bergelimang dengan harta dan kemewahan sudah mulai terjerumus ke dalam kehidupan foyafoya, berbuat dosa, dan akhirnya ia lupa pada tugasnya sebagai khalifah Tuhan di muka bumi. Mereka sakit mentalnya sehingga tidak sanggup lagi memikul beban membangun masyarakat. Dalam keadaan yang sedang sakit inilah, maka datang serbuan bangsa Mongol pada $1258 \mathrm{M}$, dan berhasil mengalahkan umat Islam dengan kehancuran kota Baghdad secara menyedihkan. ${ }^{21}$

Menyadari bahaya tersebut selanjutnya umat Islam harus introspeksi diri dengan membangun kembali etos kerja yang dipandu oleh akhlak yang mulia yang dibangun melalui tasawuf. Namun, keadaan ini terjadi secara tidak seimbang. Kaum Muslimin tampak lebih menangkap aspek ritualitas lahiriahnya dari tasawuf tersebut, asyik dalam zikir dan wirid, tanpa memberi pengaruh ke dalam gerakan sosial kemasyarakatan. Mereka malah menjauhi masyarakat, tidak peduli terhadap lingkungan dan akhirnya keadaan umat Islam semkin mundur. Dalam keadaan demikian, wajar jika kemudian dituduh sebagai biang keladi dari keadaan di mana umat Islam semakin terpuruk ke dalam kemunduran. Namun,

\footnotetext{
${ }^{20}$ Abuddin Nata, Metodologi Studi Islam (Jakarta: Raja Grafindo Persada, 1998), 279.

${ }^{21}$ Hasan Ibrahim Hasan, Sejarah dan Kebudayaan Islam (Jakarta: Raja Grafindo Persada, 2000), 128.
} 
belakangan muncul upaya reinterpretasi kembali terhadap istilah-istilah tasawuf untuk dipahami, dihayati dan diamalkan dimensi spiritualitas dan dinamikanya sehingga ia menjadi motor penggerak terjadinya perubahan sosial yang mengarah pada terwujudnya keagungan Tuhan. Bertabannus-nya Nabi Muhammad di gua Hira diartikan sebagai upaya merenung, menyusun konsep, taktik, dan strategi, serta mengumpulkan segala daya dan kemampuan untuk didayagunakan secara optimal bagi perubahan masyarakat. ${ }^{22}$ Salah satu cara yang hampir disepakati para ahli ialah dengan mengembangkan kehidupan yang berakhlak dan bertasawuf. Menurut Nasr, paham sufisme mulai mendapat tempat di kalangan masyarakat termasuk kalangan barat karena mereka mulai merasakan kekeringan batin. Mereka mulai mencari sufisme yang dapat menjawab sejumlah masalah tersebut di atas.

Setidaknya perlunya sufisme dalam masyarakat, menurut Komaruddin Hidayat, ialah agar berperan dalam berbagai upaya penyelamatan kemanusiaan dari kondisi kebingungan akibat hilangnya nilai-nilai spiritual, memberikan pemahaman tentang aspek esoterik (kebatinan Islam) baik terhadap masyarakat, dan menekankan bahwa aspek esoterik tersebut sebagai "jantung" ajaran Islam. ${ }^{23}$ Dalam hal ini, sejalan dengan pandangan Nasr menegaskan jalan rohani tasawuf atau sufisme merupakan dimensi esoterik dalam Islam yang berasal dari alQur'an dan Hadis sebagai sumber kehidupan yang paling mendasar dan utama dalam Islam. Dengan demikian, pendapat Nasr memiliki kelebihan dan kekurangannya. Kelebihannya ialah kini sebagian masyarakat mulai melirik nilai sufisme karena mereka telah merasakan kekeringan batin dan untuk membenahi akhlaknya serta menjawab semua masalah yang sedang ia hadapi. Masyarakat lebih dapat mendekatkan diri pada Tuhannya jika ia sedang menghadapi masalah. Kekurangannya ialah sebagian masyarakat masih melalaikan kewajibannya di dunia, yaitu beribadah kepada Tuhannya. Mereka masih asyik menikmati kemudahan-kemudahan yang diberikan teknologi untuk mereka.

\footnotetext{
${ }^{22}$ Nasr, Tasawuf Dulu dan Sekarang, 40.

${ }^{23}$ Nata, Akhlak Tasawuf, 294.
} 


\section{Relevansi Nilai-Nilai Sufistik bagi Masyarakat Global}

Pada abad ini manusia telah mengesampingkan Tuhan, kebenaran, perdamaian, kesadaran, kejujuran, keadilan, dan rasa kasih sayang. Manusia sudah sangat banyak berubah. Ia bukannya berusaha menemukan tiga ribu sifat Allah yang agung, tetapi malah kehilangan semua sifat itu dan membuka jalan kehancuran. Ia berusaha merusak kehidupan orang lain dan menghancurkan seluruh isi dunia. Manusia, dengan segala alat perusak yang ditemukannya, pada akhirnya hanya akan menghancurkan dirinya sendiri. Ia laksana sejenis ngengat yang tertarik dengan cahaya api, yang mengira bahwa api itu adalah makanan. Ngengat-ngengat ini berputar mengelilingi nyala api itu sampai pada akhirnya mereka terbang tepat di tengah api itu dan mati. Seperti itu pula, manusia terjerembab ke dalam perbuatan buruk, berpikir akan memperoleh manfaat darinya. Manusia memandang keburukan sebagai kebaikan, tetapi hasil akhirnya adalah kehancuran.

Tidak pernah ada kehancuran yang begitu jelas sebagaimana yang tampak pada abad ini. Manusia telah mengubah konsep tentang Tuhan, yang merupakan kebenaran, dan telah merendahkan derajad manusia, yang merupakan kebijakan dan keindahan. Mereka tidak lagi mengerti apakah sesungguhnya manusia sejati itu. Jika manusia dapat menemukan kembali siapa mereka sebenarnya, mereka akan tahu perdamaian. Jika dikatakan bahwa seseorang ingin membawa perdamaian untuk orang lain, tapi untuk melakukannya ia harus terlebih dahulu menemukannya dalam kehidupannya sendiri. Bagaimana mungkin seseorang yang tidak dapat menemukan kedamaian dalam diri mereka sendiri berharap membawa kedamaian bagi orang lain? Bagaimana seseorang yang tidak mempunyai rasa kasih sayang, kebersamaan, dan cinta dalam dirinya dapat membawa kedamaian bagi dunia? ${ }^{24}$

Untuk dapat mencapai kedamaian hidup diperlukan seseorang perlu mengenali semua aspek ciptaan di dalam dirinya dan menyadari tentang

\footnotetext{
${ }^{24}$ Bawa Muhayyadin, Tasawuf Mendamaikan Dunia (Bandung: Pustaka Hidayah, 1997), 15
} 
hakikat ilahiah. Pemikiran dan perilaku kaum sufi tersebut menjadi perhatian banyak kalangan. Dalam sejarah, bilamana aspek lahiriah, fisik dan material, telah berkembang dan stabil, maka perhatian manusia lebih tertarik kepada aspek kehidupan batin. Inilah yang menyebabkan kemunculan kaum sufi dan pengaruh mereka dalam masyarakat. Juga, bilamana situasi lahiriah masyarakat menjadi tak tertanggungkan, mengalami kebingungan, dan menderita kemelaratan, atau berada dalam keadaan sangat perlu memahami tujuan hidup, maka sekali lagi, perhatian manusia berpaling kepada pengetahuan dan pencarian jalan keluar dari situasi yang tak tertanggungkan itu.

Dalam situasi-situasi inilah pusat-pusat kaum sufi dan guru-guru sufi muncul. Bilamana materialisme, konsumerisme, dan kemerosotan yang berlebih-lebihan mencapai puncak, maka situasi itu menuntut perlunya penyeimbangan diri dengan berpaling kepada usaha menegakkan kesadaran dan kebangunan batin, yaitu saatnya tasawuf mulai bangkit. Jadi, sering kualitas hidup yang khusus dan tuntutan spesifik yang menetukan imbangan yang tepat diperlukan untuk memulihkan keseimbangan.

Kaum sufi sering disalahpahami dan kadang dianiaya. Oleh karena itu, sekali-sekali mereka harus bersembunyi untuk mengamankan dan meneruskan ajarannya secara rahasia. Ini sering merupakan akibat dari rasa takut para penguasa dan raja lalim, atau bahkan para ulama ortodoks dan pemegang kekuasaan yang merasa bahwa wewenang dan posisi keagamaan mereka dalam masyarakat sedang ditantang atau diruntuhkan oleh popularitas kaum sufi. Jalan sunyi kaum sufi seolah menjadi penghalang besar bagi orang-orang yang merasa memiliki kekuasaan di dunia karena mereka bertentangan dalam hakikat penciptaan. Mereka mencari, mencintai, dan memuja kekuasaan, sedangkan kaum sufi mencari, mencintai, dan meyembah sumber kekuasaan. ${ }^{25}$

Nilai-nilai sufistik sangat dibutuhkan bagi masyarakat global karena dapat dijadikan solusi dari masalah yang sedang dihadapi masyarakat global saat ini. Dengan mendalami ajaran agama, seseorang mempunyai

${ }^{25}$ Syekh Fadhullah Haeri, Belajar Mudah Tasawuf (Jakarta: PT. Lentera Basritama, 1990), 118. 
bekal untuk kehidupan di akhirat kelak dan dapat menjadi pegangan hidup selama di dunia. Kecenderungan nilai-nilai sufistik banyak ragamnya, antara lain klasik, tidak rasional, bagir (tasawuf positif), rasional, tasawuf mendamaikan dunia. Salah satu nilai sufistik adalah syukur. Syukur merupakan bagian dari ajaran agama, sebagaimana diisyaratkan dalam al-Qur'an Surat Ibrahim ([14]: 7) berikut ini.

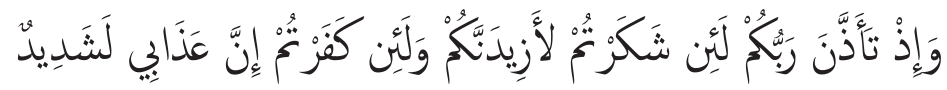

Dan (ingatlah juga), tatkala Tuhanmu memaklumkan: Sesungguhnya jika kamu bersyukur, pasti Kami akan menambah (nikmat) kepadamu, dan jika kamu mengingkari (nikmat-Ku), maka sesungguhnya azab-Ku sangat pedih.

Para ulama mendefinisikan syukur sebagai bentuk operasionalisasi dari nikmat Allah di jalan yang diridhai-Nya sesuai bentuk nikmat itu. Bila nikmat berupa mata yang dapat melihat, maka wujud syukurnya adalah menggunakan mata di jalan Allah. Seperti memperhatikan ayatayatnya yang tertulis, ataupun yang tertuang di alam semesta. Siapa saja yang menggunakan nikmat dengan baik, maka Allah akan menambah dengan nikmat lainnya, yaitu wawasan yang luas, demikian seterusnya. Sebaliknya, mereka yang tidak menggunakannya di jalan Allah, maka mereka akan mendapat azab yang pedih, seperti kebodohan, kezaliman, dan sejenisnya. Pada dasarnya selama manusia diberi nafas kehidupan, ia telah mendapat anugerah Allah. Oleh karena itu, tidak ada alasan baginya untuk tidak bersyukur, maka manusia sungguh dalam kerugian. Artinya, tidak ada kata terlambat untuk menyukuri nikmat Allah. ${ }^{26}$

Menumbuhkan spiritualitas anak, juga merupakan bentuk aktualisasi dari nilai tasawuf. Bagaimana cara mendidik anak agar menjadi anak yang shaleh dan shalehah, maka pendidikan hendaknya dilakukan sejak dini dengan menanamkan nilai-nilai agama, yang akan mengantarkan si anak sukses dunia dan akhiratnya. Sebagaimana kisah Lukman

\footnotetext{
${ }^{26}$ Ibnu al-Qayyim al-Jauzy, Sabar dan Syukur Kiat Sukses Menghadapi Problematika Hidup (Semarang: Penerbit Pustaka Nuun, 2005), 55.
} 
mendidik anaknya, antara lain ditanamkan pada anak agar tidak menyekutukan Allah dengan apapun, bersyukur kepada Allah dan kedua orang tuanya, berbuat baik kepada keduanya, menghindari kesalahan sekecil apapun. Juga beberapa pelajaran lain, seperti mendirikan shalat, diajak pada kebajikan dan menjauhi kemungkaran, ditanamkan sikap sabar dalam banyak hal, ditekankan untuk tidak sombong, sopan-santun, dan lainnya. Islam mengajarkan kepada umat manusia berdoa (memohon kepada Allah Yang Maha Pemberi Hidayah, yang paling kuasa membuka hati seseorang), mengingat manusia memiliki tiga kekuatan sekaligus, yaitu emosional, rasionalitas, dan spiritualitas. ${ }^{27}$ Oleh karena itu, perlu upaya untuk menumbuhkembangkan sikap yang baik, yakni dengan memaadukan aspek emosi, rasional, dan spiritual secara seimbang. Untuk menumbuhkan aspek emosi dan rasional, seorang anak dididik dengan ilmu dan moral, tetapi untuk aspek spiritual perlu adanya, selain upaya yang sabar dalam mendidik dan menjadikan orang tua sebagai teladan bagi anak-anaknya, juga permohonan doa kepada Allah.

Iman dan antusiasme terhadap hal-hal yang bermanfaat juga dapat dijadikan solusi pada masyarakat global yang penuh dengan problematika ini. Jika jihad di jalan Allah merupakan amal yang paling utama di sisi Allah, dan ia merupakan buah kesempurnaan iman kepada Allah maka antusiasme terhadap segala hal yang bermanfaat bagi orang mukmin di dunia dan akhirat juga termasuk indikator kesempurnaan iman kepada Allah. Tidak diragukan lagi bahwa menghiasi diri dengan perilaku keutamaan dan menjauhkan diri dari perilaku kenistaan merupakan hal yang bermanfaat bagi orang mukmin dalam urusan agama dan dunianya sehingga harus dilakukan dengan penuh antusiasme. ${ }^{28}$

Selain nilai-nilai tasawuf, dalam menjalani kehidupan manusia juga tidak bisa lepas dari moral. Singkatnya, dapat ditegaskan bahwa moral merupakan suatu fenomena kemanusiaan yang universal. Moral hanya

${ }^{27}$ Amin Syukur, Tasawuf Bagi Orang Awam Menjawab Problem Kehidupan (Yogyakarta: Pustaka Pelajar, 2006), 67.

${ }^{28}$ Muhammad Fauqi Hajjaj, Tasawuf Islam \& Akhlak (Jakarta: Penerbit Amzah, 2011), 237. 
ada pada manusia, tidak terdapat pada makhluk lain. Dengan demikian, moral menjadi salah satu pembeda antara manusia dan binatang. Manusia adalah binatang plus karena mempunyai kesadaran moral. Moral menjadi ciri khas manusia yang tidak dapat ditemukan pada makhluk di bawah tingkat manusiawi. Pada level binatang tidak tidak ada kesadaran baik buruk, tentang yang boleh dan dilarang, tentang yang harus dilakukan dan tidak pantas dilakukan. Keharusan moral didasarkan pada kenyataan bahwa manusia mengatur tingkah lakunya menurut kaidah-kaidah atau normanorma. Norma merupakan hukum. Selanjutnya, manusia harus menaklukan diri untuk tunduk pada norma-norma itu. ${ }^{29}$

Kini dunia modern dihadapkan paling tidak pada tiga persoalan dalam moral. Pertama, pluralisme moral. Dalam masyarakat yang berbeda sering terlihat nilai dan norma yang berbeda, bahkan masyarakat yang sama bisa ditandai oleh pluralisme moral. Kedua, sekarang timbul banyak masalah moral baru yang dulu tidak terduga. Ketiga, dalam dunia modern tampak makin jelas adanya kepedulian terhadap wacanawacana moral universal. Pluralisme moral terutama dirasakan karena sekarang manusia hidup di tempat-tempat suasana kemajuan teknologi komunikasi dan informasi. Melalui komunikasi modern, informasi dari seluruh penjuru dunia langsung dapat masuk ke rumah-rumah, sebagaimana kejadian-kejadian di dalam masyarakat tersiar ke seluruh pelosok dunia. Suka atau tidak, bersamaan dengan itu berkenalan dan bersentuhan dengan norma dan nilai masyarakat lain yang tidak selalu sejalan, bahkan bertentangan dengan norma dan nilai yang dianut dalam masyarakat tersebut. ${ }^{30}$

Ciri lain dari situasi kehidupan sekarang adalah munculnya masalahmasalah moral baru akibat perkembangan ilmu dan teknologi, khususnya ilmu-ilmu biomedis. Persoalan-persoalan baru itu misalnya tentang manipulasi genetis, khusunya manipulasi dengan gen-gen manusia dan kloning. Dalam situasi pluralisme moral itu, muncul kepedulian terhadap

${ }^{29}$ Bertens, Etika (Jakarta: Gramedia Pustaka Utama, 1994), 11.

${ }^{30}$ Abdul Jamil, Moralitas al-Quran dan Tantangan Modernitas (Yogyakarta: Penerbit Gama Media, 2002), 35. 
upaya pengembangan konsep moral universal. Globalisasi tampaknya tidak saja merupakan gejala di bidang ekonomi, tetapi juga di bidang moral. Dapat disaksikan adanya gerakan-gerakan perjuangan moral yang aktif pada taraf internasional. Bisa dalam bentuk kerja sama antarlembaga swadaya masyarakat (LSM), antarparlemen, dan sebagainya. Lebih penting lagi adalah suatu kesadaran moral universal yang terorganisir tidak mungkin muncul tanpa dilatarbelakangi oleh kesadaran moral universal. Gejala paling mencolok tentang kepedulian moral itu adalah munculnya Universal Declaration of Human Right yang diproklamasikan PBB pada 10 Desember 1948. ${ }^{31}$

Di dalam al-Qur'an, ada ungkapan baik dan buruk sebagai bagian terpenting dari moral. Jadi, dengan mengetahui konsep "baik" dan "buruk" dalam al-Qur'an dapat diperoleh konsep moral dalam al- Qur’an. Ungkapan "baik" terekspresikan melalui istilah-istilah shalih, birr, ma'ruf, khair, hasan, tayyib dan halal. Dalam penelitian ini, penulis menggunakan istilah "birr". Kata al-birr adalah suatu dari sekian banyak kata yang merupakan ungkapan etika keagamaan dalam al-Qur'an. Jika etika dipahami sebagai teori tentang baik dan buruk, konsep etika keagamaan dalam al-Qur'an selain terekspresi melalui kata al-birr juga terekspresi melalui kata-kata salihat, ma'rifat, hasan, tayyib, dan halal. Semua kata ini mengandung makna baik. Lawannya adalah kata-kata fasad, munkar, sharr, sayyiah, khabith, haram, dan dosa yang mengandung makna buruk. Kata al-birr memiliki makna yang strategis bagi upaya pengembangan kesalehan sosial dalam Islam. Hal ini dapat dilihat dari maknanya yang tidak saja berdimensi kebaikan vertikal tetapi juga berdimensi horizontal. Ungkapan haji mabrur yang sangat populer itu berasal dari kata al-birr. Tetapi, tampaknya kita jarang bahkan mungkin tidak pernah mengidentifikasikan makna haji mabrur melalui makna al-birr. Oleh karena itu, wajar jika implementasi kesalehan sosial ibadah haji terasa kurang terwujud sebagaimana mestinya. Hikmah lain dari makna albirr adalah beberapa aspek sosial moral yang begitu integral bagi ibadah dalam Islam. Tampaknya ini menjadi tugas bersama untuk mengubah

\footnotetext{
${ }^{31}$ Ibid., 37.
} 
orientasi ibadah, yang selama ini memiliki orientasi eskatologis ke arah yang lebih konkret empiris pada pembentukan tatanan sosial yang bermoral. Hal ini sebagaimana yang dikatakan Fazlur Rahman bahwa tujuan pokok al-Qur'an adalah membentuk tata sosial yang bermoral. Ibadah ritual, seperti shalat, zakat, puasa, dan haji dilakukan untuk membentuk moral, bukan sekadar untuk cari pahala. Oleh karena itu, sangat ironis ketika seseorang yang telah menjalankan shalat, zakat, puasa, dan haji masih memiliki penampilan moral yang tidak terpuji di tengah-tengah kehidupan sosialnya. Lebih parah lagi, jika orang tersebut berani mengandalkan jumlah pahala yang akan diterimanya di akhirat kelak dengan ibadahnya itu. ${ }^{32}$

Nilai-nilai tasawuf yang kuno tidak selamanya jelek atau tidak sesuai dengan modern. Tetapi, masih ada yang sesuai dengan modern melalui kontekstualisasi. Salah satunya nilai-nilai sufistik yang dianut Imam Nawawi. Imam Nawawi menulis sebuah kitab yang berjudul Nashāihul ' $I b \bar{a} d$, yang berisi berbagai nasihat untuk umat Muslim yang sedang mengalami problematika di zaman modern. Nasihat-nasihat tersebut berupa materi-materi bimbingan Islam yaitu akidah, akhlak, ibadah dan syariah yang dapat diamalkan dalam kehidupan sehari-hari agar kita dapat menjadi umat Muslim yang takwa dan senantiasa menjalani hidup dengan selalu berpedoman pada petunjuk Allah, yaitu al-Qur'an dan Hadits. Dengan selalu berusaha dan bersyukur kepada Allah, maka hidup menjadi aman, nyaman, tenteram, dan terhindar dari perbuatan dosa atau maksiat, serta tidak mudah tergoda oleh kesenangan-kesenangan yang ada di dunia.

\section{Penutup}

Problematika masyarakat global dewasa ini antara lain desintegrasi ilmu pengetahuan sehingga berbagai ilmu yang berjalan sendiri-sendiri tanpa ada tali pengikat dan penunjuk jalan yang menguasai semuanya. Hal ini juga seiring dengan kepribadian yang terpecah, nilai-nilai spiri-

\footnotetext{
${ }^{32}$ Ibid., 43.
} 
tual terkotak-kotak dan dangkal, ditambang dengan penyalahgunaan ilmu pengetahun dan teknologi. Selain itu, pendangkalan iman menjadi sebuah permasalahan yang cukup memprihatinkan. Dengan adanya pola hubungan materialistik yang ditentukan oleh seberapa jauh antara satu dan lainnya dapat memberikan keuntungan yang bersifat material. Perilaku yang menghalalkan segala macam cara muncul akibat dari dangkalnya iman dan pola hidup materialistik manusia, yang pada akhrinya akan menyebabkan stres dan frustasi. Jika semua permasalahan tersebut tidak dapat diatasi, maka risiko kehilangan harga diri dan masa depan adalah suatu hal yang pasti akan terjadi.

Di tengah semua problematika yang dihadapi pada era kekinian ini, kita perlu melihat semua permasalahan ini dalam perspektif Islam, bagaimana agama melihat permasalahan ini sesungguhnya. Oleh karena itu, dibutuhkan beberapa solusi untuk mengatasi masalah tersebut, antara lain, pertama, menerima ujian dan cobaan dengan sabar dan tabah karena hal ini merupakan kunci kedewasaan emosional; kedua, prinsip keseimbangan antara duniawi dan ukhrawi; ketiga, menjalankan perintah Allah dan menjauhi larangan-Nya. Meraih kebahagiaan di dunia dan akhirat merupakan keberhasilan yang dapat dicapai dengan memahami betul ajaran Islam, maka dari itu sangat penting adanya bimbingan penyuluhan Islam agar kehidupan masyarakat sesuai dengan nilai-nilai keislaman.

\section{DAFTAR PISTAKA}

Arikunto, Suharsimi. Prosedur Penelitian Suatu Pendekatan Praktik. Jakarta: Rineka Cipta, 1997.

Bhaidawy, Zakiyuddin. Dialog Global \& Masa Depan Agama. Surakarta: Muhammadiyah University Press, 2001.

Bertens, Kees. Etika. Cet. II. Jakarta: Gramedia Pustaka Utama, 1994.

Burkhadrt, Margareth A. "Characteristics of Spirituality in the Lives of 
Women in a Rural Appalachian Community." Journal of Transcultural Nursing, Vol. 4, Issue 2 (1993).

Chaidar. Sejarah Pujangga Islam Syekh Imam Nawawi al-Bantani. Jakarta: Sarana Utama, 1978.

Dahlan, Abdul Aziz. Ensiklopedia Tematis Dunia Islam. Jakarta: PT Ichtiar Baru Van Hoeve, 2002.

Depag RI. Al-Qur'an dan Terjemahnya. Jakarta: Lembaga Pentafsir dan Penterjemah Al-Qur'an, 1997. . Ensiklopedi Islam di Indonesia. Jakarta: CV. Anda Utama, 2003.

Hajjaj, Muhammad Fauqi. Tasawuf Islam \& Akhlak. Jakarta: Penerbit Amzah, 2011.

Haeri, Syekh Fadhullah. Belajar Mudah Tasawuf. Jakarta: PT. Lentera Basritama, 1990.

Harahap, Syahrin. Metodologi Studi tokoh Pemikiran Islam. Jakarta: Istiqamah Mulya Press, 2006.

Hasan, Hasan Ibrahim. Sejarah dan Kebudayaan Islam. Jakarta: PT. Raja Grafindo Persada, 2000.

Jamil, Abdul. Moralitas al-Quran dan Tantangan Modernitas. Yogyakarta: Penerbit Gama Media, 2002.

al-Jauzy, Ibnu al-Qayyim. Sabar dan Syukur Kiat Sukses Menghadapi Problematika Hidup. Semarang: Penerbit Pustaka Nuun, 2005.

Jawas, Yazid bin Abdul Qadir. Syarah 'Aqidah Ahlus Sunnah wal Jama'ah. Jakarta: Pustaka Imam Asy-Syafi'i, 2006.

Muhadjir, Noeng. Metodologi Penelitian Kualitatif. Yogyakarta: Rake Sarasin, 1996.

Muhayyadin, Bawa. Tasawuf Mendamaikan Dunia. Bandung: Pustaka Hidayah, 1997.

Munir, Muhammad dan Wahyu Ilaihi. Manajemen Dakwah. Jakarta: Prenada Media, 2006. 
Mutaqien, Ma'ruf. "Eskapisme Masyarakat Modern,”

http://immciputat20.blogspot.co.id/2005/08/kliping-media.html. Diakses pada 20 April 2018.

Nasr, Seyyed Hossein. Tasawuf Dulu dan Sekarang. Jakarta: Pustaka Firdaus, 1985.

Nata, Abuddin. Akhlak Tasawuf. Jakarta: PT. Raja Grafindo Persada, 1997. Metodologi Studi Islam. Jakarta: PT. Raja Grafindo Persada, 1998.

Nasution, Harun. Islam Rasional Gagasan dan Pemikirannya. Bandung: Mizan, 1989.

Sutoyo, Anwar. Bimbingan dan Konseling Islami. Semarang: CV. Cipta Prima Nusantara, 2007.

Syukur, Amin. Tasawuf Kontekstual Solusi Problem Manusia Modern. Yogyakarta: Pustaka Pelajar, 2003. . Tasawuf Bagi Orang Awam Menjawab Problem Kehidupan. Yogyakarta: Pustaka Pelajar, 2006.

Ulwan, Abdullah Nasihin. Aktivitas Islam Menghadapi Tantangan Global. Solo: al-Alaq, 2003. 